\title{
SOLAR POWER
}

Sun is the source of all energy in our solar system. New technology in solar power is improving the system and can be expected to make this power competitive with other traditional sources. Presently, electricity from very large scale solar system will cost about 18 cents per kWh. Nanosolar company based in San Jose, California, USA claims that its new technology can generate electricity at 5-6 cents per kWh. Many experts believe that within a decade or so it will be competitive with other sources of energy. A study done by Greenpeace International and other European Agencies shows that concentrated solar power (CSP) could account for up to $25 \%$ of the World's Energy needs by 2050. However, due to advances in nano solar technology it may replace CSP. Solar energy will be major component in future as expensive infrastructures like dams for hydropower will not be required.

CSP is a system that use lens or mirrors to concentrate a large area of sunlight into a small area. The concentrate light is converted to heat which drives a heat engine (steam turbine) to produce electrical power. Various systems are used for CSP i.e. parabolic trough, dish sterling, linear fresnel reflector, and solar power tower. This system tracks the sun. Spain is the leader in CSP plants installed. CSP plants are under construction in Algeria, Egypt, Italy and Morocco, and of course in Spain. In both Spain and the United States a large number of CSP plants have been proposed. Power storage for CPS systems typically takes the form of storing heat for later use, as opposed to some PV systems which use battery backup systems to store electric charge.



Dish Engines

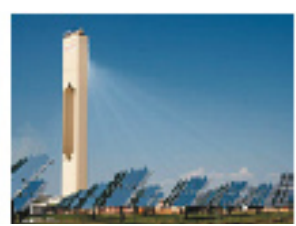

Solar Tower

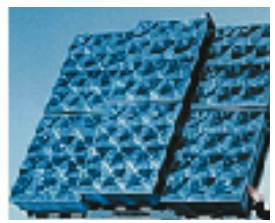

Freshnel Lenses
The EU has begun to look into developing a $€ 400$ billion ( $\$ 774$ billion) solar power plant based in the Sahara region using CSP technology known as Desertec. It is part of a wider plan to create "a new carbon-free network linking Europe, the Middle East and North Africa". The plan is backed mainly by German industrialists and predicts production of $15 \%$ of Europe's power by 2050 . Morocco is a major partner in Desertec and as it has barely $1 \%$ of the electricity consumption of the EU, it will produce more than enough energy for the entire country with a large energy surplus to deliver to Europe.
In 2009, scientists at the National Renewable Energy Laboratory (NREL) and SkyFuel teamed to develop large curved sheets of metal that have the potential to be $30 \%$ less expensive than today's best collectors of concentrated solar power by replacing glass-based models with a silver polymer sheet that has the same performance as the heavy glass mirrors, but at a much lower cost and much lower weight. It also is much easier to deploy and install. The glossy film uses several layers of polymers, with an inner layer of pure silver.

There are four main CSP designs currently in use at the utility scale: parabolic troughs, tower systems, parabolic dishes and linear (Fresnel) troughs. Parabolic troughs currently account for over $90 \%$ of the generation capacity in installed CSP, however many in the solar industry speculate that tower systems will become more widely used than parabolic troughs in the future.

Parabolic troughs: Parabolic trough systems consist of rows of curved mirrors that concentrate the sun's rays into a central tube containing the fluid to be heated. The mirrors utilize a tracking system to follow the sun, typically rotating on one north-south axis. The sunlight on the mirrors is concentrated 70-100 times and the fluids are heated to temperatures as high as 400 degrees Celsius. Many of these systems use synthetic thermal oil, which is used to create super-heated steam to run turbines.

Dish engines: Dish engines use parabolic dishes to concentrate sunlight onto a receiver in the focal point of the dish, heating a fluid which then runs a turbine or sterling engine. These technologies typically heat fluids to 750 degrees Celsius.

Solar Tower systems: Tower systems use a field of heliostats (large mirrors with sun-tracking capabilities) focused on a single point in a tower to heat a fluid. Tower systems concentrate sunlight 600-1000 times to heat transfer fluids including molten salts, water, air and other gases from 800 to over 1000 degrees Celsius.

Linear (Fresnel) troughs:Linear troughs operate similar to parabolic troughs, except that the mirrors used are flat and much of the hardware is simpler. These systems cost less than parabolic trough systems, but are less efficient.

In Southern California, USA the 354 MW Solar Energy Generating Systems, constructed in 1984 is still the largest solar power plant in the world. 


\section{Nano Technology}

Scientists have come up new approach that concentrates solar power by 100 times without needing any lense, or mirrors. It is called 3 rd Generation solar power technology in the form of solar cell's printed with nano particle painted on a metal foil. This Nano technology is not a matter for present research laboratory for future possibilities. Nano technology is already producing electricity in the field. The efficiency of the new panels is about $11 \%$. In future its efficiency is expected to increase. Thin film solar panels will replace Silicone wafers. Organic solar cells will be able to paint in flexible plastic sheets or may be painted building walls and roofs. One day exterior walls and roof of the buildings can be painted with nano solar cells. The electricity generated will be in excess of the internal requirement of the house.

Photovoltaic thin film semi conductors named CIGS (Copper Indium Gallium Diselenide) is painted with a proprietary nano particle ink. Since the proprietary ink is painted on rolls of metal foils that are metre wide and a mile long, it can be cut to any sizes. The nano solar cells will have payback period in months not in years. The new flexible plastic solar panels are inexpensive and easy to make. Developing organic solar cells from polymers, is cost effective. Two advantages over earlier

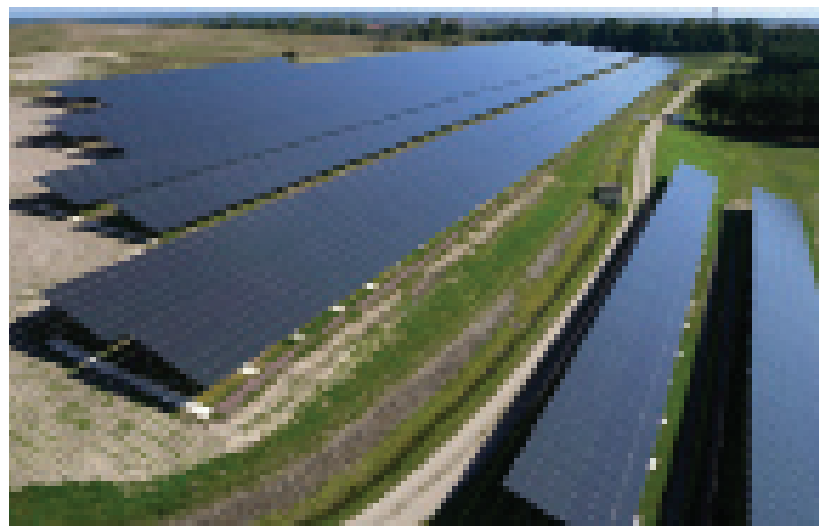

1.1 MW Nano Solar System in Germany technologies are that printing process is quick and also makes it easy to deposit a uniform layer of the ink.

Nanosolar has developed and commercialized a lowcost printable solar cell manufacturing process with proprietary ink. At present, it is selling only Utility level system. Nanosolar claims to be able to produce electric-

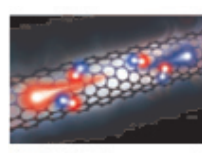

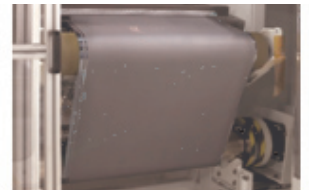

Panel Production

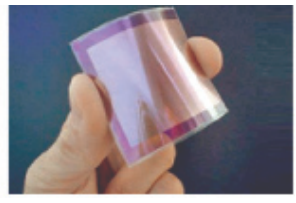

Flexible Nano ity at 5-6 cents/kilowatt hour almost as cheap as power from coal and at about one-third the cost of other solar panel. It claims mass production of solar power will now become feasible with their differently manufactured solar panels. Conventional silicon-made solar panels have a stiff competitor from CIGS semiconductor printed solar panels - composed of copper, gallium, indium and selenium - which perform as good as conventional solar panels in lab conditions. An inexpensive printing process makes it ideal for mass production by an automated facility with robots and other hi-fi equipment.

Nanosolar is building a panel manufacturing plant in Lukenwalde (Berlin). In Germany there is a favorable government subsidy plan for solar energy. Germany has installed a 1.1 MW solar plant based on the nano technology of Nanosolar in Lukenwalde.

\section{- Compiled By Jeewan P. Thanju from various internet sources which are duly acknowledged}

\section{References}

http://www.alternative-energy-news.info/nanosolarsolar-power-lower-cost/

http://en.wikipedia.org/wiki/Concentrated_solar_ power

\section{CALENDAR OF EVENTS}

\section{IRRIGATION}

24-25 February 2011, Canal Automation, Location: New Delhi, India, Contact Person: Mr. V.K. Kanjlia, Secretary. More info: E-Mail: uday@cbip.org; cbip@ cbip.org

21-24 March 2011, Minia International Conference for Agriculture and Irrigation in the Nile Basin Countries, Location: El-Minia, Egypt. More info:Website: http:// micma2011.org

Contact name: Prof. Dr. Kasem Zaki Ahmed.

16-20 May 2011, 25th European Regional Conference
ICID, Location: Groningen, The Netherlands. More info: Email: bert.toussaint@rws.nl, Website: www.icid2011. nl, www.nethcid.nl, Email: nethcid2011@rws.nl

15-23 October 2011, 8th International Micro Irrigation Congress. Location: Tehran, Iran. More info: E-mail : irncid@gmail.com, icid2011@gmail.com, Website : http://www.icid2011.org

15-23 October 2011, 21st International Congress on Irrigation and Drainage, Location: Tehran, Iran. More info: E-mail : irncid@gmail.com, icid2011@gmail.com, Website : http://www.icid2011.org 